\title{
Etnograafilised välitööd kunsti peeglis
}

\author{
Elo-Hanna Seljamaa \\ Tartu Ülikooli eesti ja võrdleva rahvaluule osakonna vanemteadur \\ elo-hanna.seljamaa@ut.ee
}

\begin{abstract}
Teesid: Artikkel heidab pilgu rahvusvahelistesse diskussioonidesse kaasaegse kunsti ja empiirilise kultuuriuurimise (antropoloogia, etnoloogia, folkloristika) suhte üle, keskendudes ühelt poolt etnograafiliste välitöömeetodite kasutamisele kaasaegses kunstis ning teisalt loomeuurimuse mõistele, selle määratlustele ja määratlematusele.

Käsitlus tõukub kunstnik Eve Kase portreesarjast oma Lasnamäe majanaabritest, mille loomise protsess sarnanes artikli autori etnograafiliste välitöödega etniliste vastassuhete teemal samas linnaosas. Nii kunstnikul kui ka uurijal tuli oma töö tegemiseks rikkuda käitumisnorme ja ületada (keele)piire, mis vaikimisi liigendavad argielu Tallinnas. Lähem vaatlus näitab, et metodoloogiline ja temaatiline ühisosa ning jagatud kogemused kätkevad endas olulisi erinevusi, mis tulenevad töötamisest ja enda väljendamisest vastavalt visuaalide ja sõnadega. Ühtlasi kõnelevad need erinevused sellest, mis on ainuomane loomeuurimusele kui uurimusele kunstis.
\end{abstract}

Märksõnad: empiiriline kultuuriuurimine, etnilisus, etnograafia, kaasaegne kunst, Lasnamäe, loomeuurimus, välitööd

Mitmed tänased Eesti kunstnikud käsitlevad identiteedi, rahvusluse, etnilisuse ja või laiemalt kuulumisega seotud teemasid, ${ }^{1}$ millega ma ise tegelen folkloristina etnograafiliste meetodite toel. Nende loominguga tutvudes ja vahel ka sellest kirjutades (nt Seljamaa 2011, 2014, 2019) olen tabanud end mõtisklemast sarnasustest ja erinevustest kultuuriuurija ja kunstniku töös ning väljendusvahendites. Nii üks kui teine võib justkui teha välitöid: viia läbi vaatlusi ja intervjuusid, teha märkmeid ja pidada päevikut, pildistada, filmida ning käsitletava teemaga seonduvat muul viisil dokumenteerida, töötada läbi arhiive. Isegi materjalide kogumise paik või väli võib olla sama või vähemalt väga sarnane. Mõlema puhul võib ilmselt rääkida etnograafiast kui metodoloogiast, mis "hõlmab pikaajalist, tähendusrikast ja otsest kontakti" inimestega ja nende argielus osalemist (Annist et al. 2017: 62). Ometi on tulemus erinev. Vahel näib mulle, et kunstniku õnnestunud foto, video, installatsioon või muu taies ütleb rohkem kui uurija sada või isegi tuhat sõna. Sõnadega töötades on keeruline vältida otse välja ütlemist, paika panemist, isegi kui eesmärk on 
välja tuua näiteks kuulumise ja mitte-kuulumise kogemuste suhtelisust ja ambivalentsust - paikapanematust. Sõnadest jääb puudu ja sõnulseletamatu sunnib vaikima (Seljamaa \& Siim 2016). Teinekord tõden endamisi, et mis on lubatud kunstnikule, ei ole lubatud uurijale. Või kas ikka on? Aga vastupidi? Mis teeb kunstniku pealtnäha etnograafilisest projektist kunsti ja teadlase sarnaste meetoditega läbi viidud projektist teaduse? On seal üldse vahet? Tänapäeval räägitakse ka Eestis loomeuurimisest (artistic research) ${ }^{2}$ kui ühest teaduse tegemise ja teadmise loomise viisist, eksperimenteeritakse teadlaste ja kunstnike koostööga ning Eesti Kunstiakadeemias (EKA) ja Eesti Muusika- ja Teatriakadeemias kaitstakse loomeuurimusel põhinevaid doktoritöid (nt Alver \& Taavet 2017; Kelomees 2018; Lankots 2016; Pesti 2018; Piirma \& Valk 2014).

Käesoleva käsitluse ajendiks on koostöö kunstnik Eve Kasega ${ }^{3}$ ning eriti tema üks fototeos, "Kärberi 37" (2004) - 49 portreest koosnev seeria kunstniku majanaabritest Lasnamäel. "Kärberi 37" paelub mind, sest sellest fotode sarjast ja selle valmimise protsessist vaatavad mulle piltlikult öeldes vastu minu enda etnograafilised välitööd. Tegin aastatel 2009-2011 välitöid doktoritöö tarbeks, mis käsitles etnilisust, rahvuslust ja lõimumist Eestis (Seljamaa 2012), ning veetsin sellega seoses üksjagu aega Lasnamäel. Toona näis see Tallinna venekeelseim ja rahvuslikult koosseisult kõige mitmekesisem linnaosa mulle etniliste vastassuhete uurimiseks loogilise alguspunktina. Seda ka põhjusel, et mulle imponeeris Rogers Brubakeri ja tema mitmete kaasautorite arendatud käsitus etnilisusest ja rahvusest kui kategooriatest, mida erinevad toimijad - üksikisikud, riik, organisatsoonid jne - kasutavad maailma mõtestamiseks. Selle lähenemise järgi ei ole näiteks rahvus või etniline grupp reaalselt eksisteerivad "asjad", vaid tõlgenduslikud raamid, mille järele teatud olukorras haaratakse või mille kasuks otsustatakse - või siis mitte (nt Brubaker 2006; Brubaker et al. 2004, 2006). Võttes eeskujuks Rogers Brubakeri, Margit Feischmidti, Jon Foxi ja Liana Grancea mahuka etnograafilise uurimuse "argisest etnilisusest" (evereyday ethnicity) Clujis ehk Kolozsváris, varem Ungari koosseisu kuulunud Rumeenia linnas (Brubaker et al. 2006), lootsin minagi Tallinnas jälgida, kuidas ja millal Eestis omavahel tihedalt seotud etnilisuse ja rahvuse kategooriad aktualiseeruvad ja käiku lastakse.

Brubakeri ja tema kolleegide üks eesmärke oli läheneda etnilisusele ja rahvusele kaude, ilma et nad oleksid välitöid tehes antud teemade vastu otsest huvi üles näidanud. Selle taga oli soov mitte sekkuda etnilisuse pidevasse taasloomisesse - vastavaid tõlgendusraame mitte esile kutsuda (Brubaker et al. 2006: 15). Ma ei tea, kuidas neil, aga minul selline vaikselt tegutsemine ei õnnestunud, sest etnograaf on iseenda peamine tööriist ning minu kohaliku eestlase taust oli mul kodulinnas välitöid tehes risti ja põiki ees. See avaldus 
kõhklustes, mida näiteks Vene Kultuurikeskusesse, mõnda kohvikusse või teise "vene" kohta sisenemine minus tekitas; psühholoogilises barjääris, mida tuli kontakti võtmiseks ületada, minu kehvas vene keeles, aga ka arusaamatuses, üllatuses ja küsimustes, mida mu kohalolu ja kontaktivõtmised venekeelsetes kaaslinlastes tekitasid. Aegamööda adusin, et uurimaks etnograafiliselt argist etnilisust Tallinnas pidin rikkuma neidsamu kirjutamata reegleid ja vaikivaid kokkuleppeid, ületama sageli nähtamatuid piire "eesti" ja "vene" maailma vahel, millega olin selles samas linnas üles kasvanud, mida mind oli vaikimisi järgima õpetatud ning mille najal pealinna kakskeelne elu püsib. Nagu olen teisal (Seljamaa 2016) sõnastanud, eelistavad Tallinna eesti- ja venekeelsed elanikud igapäevaselt etnilisuse ja sedakaudu ka keele ning rahvusega seotud teemasid summutada või vaigistada. Rahvusest ja keelest numbri tegemine tähistab pingeid ja konflikti, tülikat katkestust argielu voos. Seega aitab "etnilisuse vaigistamine" tagada igapäevaelu sujuvust ja ühises linnaruumis hakkama saada, hoides samas alal keelepõhist segregatsiooni ning etniliste identiteetide erisust. ${ }^{4}$

Nagu artikli teises pooles arutlen, on Lasnamäel majanaabreid pildistav eestikeelne kunstnik või võõraste venekeelsete kaaslinlastega kontakti otsiv eestikeelne folklorist sarnases olukorras. Mõlemad kompavad piire ja norme, mis argielu nähtamatult struktureerivad ja käigus hoiavad, muutes need nähtavaks ja katkestades vaikuse, kasvõi ajutiselt. Hoolimata ühisosast meetodite vallas on nende tööprotsess ja tulemused erinevad. Artikli esimeses osas teen sissevaate rahvusvahelistesse diskussioonidesse kaasaegse kunsti ja empiirilise kultuuriuurimise ${ }^{5}$ suhte üle, keskendudes etnograafiliste meetodite kasutamisele kaasaegses kunstis ning selle kaudu loomepõhise, täpsemalt kunstipõhise uurimistöö defineerimise võimalustele ja võimatusele. Üheks läbivaks, erinumbri teemaga haakuvaks küsimuseks on siin verbaalse ja mitteverbaalse suhe tööprotsessis ja selle tulemuste tutvustamises. Kaudsem seos vaikuse teemaga avaldub tõigas, et nimetatud teemasid on eesti keeles käsitletud pigem vähe, kuigi need võiksid huvi pakkuda nii empiirilistele kultuuriuurijatele kui kunsti vallas tegutsejatele ning on ka õppetöös aktuaalsed. Etnoloogia ja folkloristika magistrantuuris Tartu Ülikooli kultuuriteaduste instituudis õpib järjest rohkem kunstitaustaga üliõpilasi ning õpingud võib lõpetada magistriprojektiga, milleks võib olla ka näitus või muu visuaalne väljund. Sagenenud on ka kunstnike koostöö ajaloolaste ja empiiriliste kultuuriuurijatega mäluasutuste kontekstis (nt Eesti Rahva Muuseumi uus Eesti püsiekspositsioon, taasavatud Vabamu). 


\section{Kunstnik kui etnograaf?}

Etnograafiliste meetodite rakendamine kunstis ning kunsti ja antropoloogia vahekord laiemalt on viimase veerandsaja aasta jooksul palju tähelepanu pälvinud (nt Coles 2000; Grimshaw \& Ravetz 2015; Ingold 2013; Marcus \& Myers 1995; Schneider \& Wright 2010; Rutten et al. 2013). Kunsti puhul on räägitud etnograafilisest pöördest, millele sillutas teed 1980. aastatel USAst alguse saanud varasema antropoloogilise traditsiooni refleksiivne ja kriitiline analüüs. Tõe ja terviklikkuse nõudlemise asemel tõusid fookusesse varasemate uurijate loodud tekstuaalsed representatsioonid oma erapoolikuses ja konventsionaalsuses, mille analüüsi kaudu avati "teise" kujutamisega seotud võimusuhete problemaatikat (vt eesti keeles nt Annist et al. 2017: 50-52; Kuutma 2005: 8-11; samuti Clifford \& Marcus 1986; Clifford 1988). Sellega kaasnenud etnograafia ümber mõtestamine kultuuri kirjeldamise ja kirjutamisena avaras mõttes ja võtmes muutis etnograafilise metodoloogia omamoodi vabavaraks, mille järele võisid haarata ka kunstnikud. Kunstis hakati samal ajal enam tähelepanu pöörama protsessile ja performance'itele ning esile tõusid visuaalsed meetodid. Nii ühel kui ka teisel väljal tõusid huviorbiiti praktikad (Alver \& Taavet 2017: 104-105; Grimshaw et al. 2010: 160; Pink 2001).

USA kunstiteadlane Hal Foster avaldas 1990. aastate keskel George E. Marcuse ja Fred R. Myers'i toimetatud kunsti ja antropoloogia teemalises kogumikus tänini vastukaja tekitava (nt Grimshaw \& Ravetz 2015; Rutten et al. 2013; Siegenthaler 2013) artikli "Kunstnik kui etnograaf?", milles ta hoiatas kvaasi- ja pseudoetnograafia eest. Fosteri (1995) hinnangul nopivad kunstnikud antropoloogide tööriistakastist välja mõned neile sobivad vahendid ja rakendavad välitööd ning nende käigus kohatud inimesed ja kogukonnad oma isikliku kunstilise visiooni ja ambitsiooni teenistusse, pööramata piisavat tähelepanu näiteks eetilistele küsimustele. Tulemuseks on kunst, mis taastoodab hierarhilisi suhteid ja eksotiseerivat teisestamist, selmet neid dekonstrueerida ja kritiseerida. Fosteri arvates (1995: 305) tõmbabki antropoloogia kunstnikke ligi sellepärast, et see tegeleb Teise ja teisesuse ning kultuuriga. Sarnaselt kunstile on see kontekstisidus ja -tundlik, interdistsiplinaarsusele avatud ning rõhub refleksiivsusele.

Viisteist aastat hiljem valminud essees nõustub Marcus (2010) mitmete Fosteri tähelepanekutega, kuid märgib ka, et antropoloogid ei saa etnograafilisi meetodeid pelgalt enda omaks pidada. Näiteks teatri ja filminduse vallas on sarnaseid võtteid kasutatud antropoloogiast sõltumata ja viisidel, mis võiksid huvi pakkuda ka empiirilistele kultuuriuurijatele. Ka rõhutab ta, et maailm on 1980. aastatest saadik kiiresti ja radikaalselt muutunud, mistõttu on muutunud ka välitööd ning tekkinud vajadus uute, uusi tingimusi hõlmavate välitöömee- 
todite järele. Leidub õnnestunud näiteid antropoloogia kasutamisest kunstis ning isegi kui kunstnikud klassikalisi etnograafilisi meetodeid eeskujulikult ei rakenda, võiksid uurijad kunstnike praktikatest ja eksperimentidest oma välitöömetodoloogia uuendamiseks inspiratsiooni saada (Marcus 2010: 85-87). Teisenevad ka käsitused Teisest ja teisesusest. Nii rõhutab erinevate meediumitega (nt video, skulptuur, tants, muusika, foto) töötav Renate Lorenz (2017: 34), küll allpool jutuks tuleva loomeuurimusega seoses, vajadust ühelt poolt erinevust kui erilisust kinnitada ja jaatada ning teisalt võidelda "erinevuse režiimidega", kus erinevus ilmneb hierarhia, sotsiaalse ebavõrdsuse või väljajäetusena.

\section{Etnograaf ja kunstnik?}

Etnograafiline pööre kaasaegses kunstis toimus umbes samal ajal, kui empiirilises kultuuriuurimises hakati pöörama tähelepanu meelelistele kogemustele ja emotsioonidele (Rutten et al. 2013: 460-461; Pink 2006). Kumbki neist ei pruugi sõnadesse sobituda ega vaatlemise teel selgeks saada ning mõlemad on kunsti tegemisel olulised. Kunsti ja antropoloogia suhete teemal mitmeid käsitlusi avaldanud Arnd Schneider ja Christopher Wright (2010: 6) toovad lõhna näite, sest lõhnu olevat kultuuri- ja sotsiaalteadlastel kõige keerulisem vahetult uurida. Teha uurimistööd lõhnade teemal (about smell) on üks asi, kuid uurida lõhnade kaudu (with smell) ja lõhnadega töötada on midagi muud. Schneideri ja Wrighti arvates võiksid empiirilised kultuuriuurijad kunsti kaudu näha oma harjumuspäraseid arusaamu ja praktikaid uuest, kriitilisest perspektiivist.

Palju aastaid kunsti ja antropoloogia kombineerimisega katsetanud Anna Grimshaw ja Amanda Ravetz (2015; vt ka Grimshaw et al. 2010) seevastu peavad oluliseks kunsti ja etnograafilise kultuuriuurimise erinevuste varasemast selgemat teadvustamist ja sõnastamist. Nad toovad välja, et kunsti ja antropoloogia teemal sõna võtnud autorid defineerivad ja mõistavad etnograafiat erinevalt ning sellest tulenevalt on erinevad ka nende rõhuasetused. Näiteks võib keskenduda rohkem lõpetatud kunstiteosele (Schneider) või hoopis selle loomise protsessile (Ingold) ning vastavalt jõutakse ka erinevate ootusteni kunsti ja antropoloogia koostöö suhtes. Grimshaw ja Ravetz väidavad, et just ebakriitiline või hooletu ümberkäimine etnograafia mõistega "takistab antropoloogia ja kunsti vaheliste fundamentaalsete erinevuste tunnistamist" (Grimshaw \& Ravetz 2015: 426). Oma eksperimentidele tagasi vaadates toovad nad välja, et uurijad on kinni eetilistes küsimustes ja proovivad esteetikat sellele allutada. Alguses kunsti ja hiljem antropoloogiat õppinud ning seejärel neid kahte kombineerinud Ravetz pani tähele, et antropoloogiaõpingud "julgustasid 
teda mõtlema probleemidest, kontekstidest, tehnikatest ja vormidest sellisel viisil, et protsessi iga element sobitus loogiliselt üldisemasse raamistikku ja aitas kokkuvõttes kaasa millegi kohta teadmiste loomisele" (ibid.: 429; rõhutus originaalis). Kunstnikest õppejõudude ja kolleegide nägemuses ei suutnud ta aga "päris maailma detailidest lahti lasta", kuigi see on vajalik sisenemaks kunsti loomise seisukohast otsustavasse "transformatoorsesse ja/või üldistavasse protsessi" (ibid.).

Grimshaw ja Ravetzi tähelepanekute kohaselt võib uurijate vähene või olematu huvi vormi ja esteetika vastu kunstnikele arusaamatuks jääda, sest sageli avanebki just nende kaudu kunstis uus ja võib-olla ka asju teiseks tegev ning neid ootamatu nurga alt avav ruum. Kui antropoloogias on esteetika sisu või teadmise kandja ja selle teenistuses, siis kunstis sünnib esteetika sisu ja vormi mängust ning on selle mängu käigus loodud teadmise lahutamatu osa. Grimshaw ja Ravetzi järgi (2015: 430) on teadmisloome kunstis pigem sekkuva ja segava (disruptive) kui kumulatiivse iseloomuga. Analüüs järgneb tegemisele ja teose valmimisele, mis omakorda võib kulgeda ennustamatuid radu pidi. Kunsti ja antropoloogia vahekorra ja erinevuste üle arutlemine on nende sõnul siiski oluline, sest see võimaldab käsitleda ebatraditsioonilisi lähenemisi, mis vormiga eksperimenteerides lähevad vastuollu teaduse konventsioonidega ega ole samas esteetiliselt piisavalt ambitsioonikad, et kunstiks kvalifitseeruda. Kunsti ja antropoloogia teemaline arutelu on Grimshaw ja Ravetzi hinnangul jõudnud teatud punkti, millest edasi liikumine eeldab kunsti ja antropoloogia kui erinevate maailmaga suhestumise viiside erinevuste ja potentsiaali paremat mõistmist (ibid.: 432). Esteetilise sisenemine empiirilisse kultuuriuurimisse "uurimispraktika, mitte teema või objektina" on nende kogemuses "sügavalt rahutukstegev", potentsiaalselt uurimistööd muutev samm, mis tõstatab rea küsimusi tõelise ja kujuteldava, diskursiivse ja figuratiivse, uurijate ja uuritavate piiride kohta (ibid.: 428, rõhutus originaalis).

Vajadust kunstiloome ja etnograafilise uurimistöö praktikaid empiiriliselt uurida on rõhutanud ka teised kunsti ja antropoloogia teemalises diskussioonis osalejad (nt Rutten et al. 2013 ja kaastööd nende toimetatud erinumbrile). Fiona Siegenthaler (2013) astub sammu kaugemale, kui toob mängu kunstikriitikud ja teised kunstist kirjutajad. Ta väidab, et käsitlemaks ja mõistmaks etnograafilistel välitöödel põhinevaid, koha- ja kohtumiste spetsiifilisi ning sageli ka efemeerseid kaasaegseid kunstiteoseid tuleb kunsti uurijatel kasutada kunstnikega sarnaseid meetodeid. (Osalev) vaatlus, intervjuud ja teised etnograafilised meetodid võimaldaksid uurijatel kunstnike kõrval olla ning teoste sündi jälgida. Kuigi näitusesaalis eksponeeritud taies on vaid jäämäe tipp, ootavad kriitikud sellelt ikkagi, et see "omaks kunstilist väärtust, oleks kultuuriliselt tundlik, poliitiliselt aktuaalne ja esteetiliselt veenev" (Siegenthaler 2013: 747). 
Etnograafiline pööre kunstikriitikas ja -teaduses võiks aidata paremini näha ka jäämäe veealust osa.

\section{Loomeuurimuse defineerimine}

Loomeprotsessi varjust välja toomine võib oluliseks muutuda ka sel juhul, kui kunstnik ei tee "pelgalt" kunsti, vaid loomeuurimust. Etnograafiliste meetodite ja kunsti debatil ongi ühisosa loomeuurimuse üle käidavate aruteludega, kuigi loomeuurimuse mõiste ise on märksa avaram ning selle käsitlused hõlmavad ka nt teaduspoliitikat, kõrghariduse reforme ja kvaliteedi hindamist, koostööd loodus- ja tehnikateadustega ning muidugi erinevaid loomevaldkondi (vt nt Biggs \& Karlsson 2011; Borgdorff et al. 2020; Kaila et al. 2017). ${ }^{6}$

Loomeuurimuse teema teoreetilistes käsitlustes ja tutvustustes võib kohata järgnevat kolmikjaotust: uurimus kunstidest (research on the arts), uurimus kunstide tarbeks (research for the arts) ja uurimus kunstides (research in the arts) (nt Borgdorff 2012: 37-39; Kelomees 2018). Loomeuurimuse ühe teoreetiku Henk Borgdorffi (2012) sõnul on esimene neist teoreetilise ja teine rakendusliku suunitlusega ning kumbki eeldab distantsi uuriva subjekti ja tema tegevuse objekti vahel. Kolmandal juhul (uurimus kunstis) on objekti ja subjekti, teooriat ja praktikat eristada keeruline, et mitte öelda võimatu: "kunstipraktika on nii uuringu koostisosa kui ka objekt, nii meetod kui tulemus" (Kelomees 2018). Kunstnik on samal ajal nii looja kui ka uurija (Borgdorff 2012; Pesti 2018).

Aastakümneid Norras loomeuurimuse edendamisega tegelenud Søren Kjørup (2011) peab oluliseks loomeuurimuse ühestest määratlustest ja formaalsetest kriteeriumidest hoidumist, sest praktikas leidub väga erinevaid loomeuurimusi - nagu ka muud laadi uurimistööd. Kjørup viitab paralleelile humanitaarteadustega, mille heterogeensuse tundma õppimine ja tunnustamine võttis üksjagu aega (ibid.: 28-30). Arhitektuuriteadlane Epp Lankots (2016) toob välja, et "üks selgemalt eristuvaid seisukohti on, et tegemist ongi ennekõike institutsionaalse praktikaga, s.t loomepõhine uurimistöö on midagi, mida tehakse ülikooli sees ning mis on tihedalt seotud kraadiõppega”. Borgdorff, kes kuulub ka ajakirja Journal of Artistic Research ning ühingu Society for Artistic Research asutajate hulka, pakub välja seitse loomeuurimist iseloomustavat kriteeriumit (2012: 161-168, 209-212). Nii peab ta kunstipõhise uurimuse puhul oluliseks kunstniku ettekavatsetud soovi (intent) luua kunstilise tegevuse kaudu uut teadmist nii kunstimaailma kohta ja selle tarbeks kui ka teaduse ja mõistmise nimel üldiselt. Uue teadmise loomisega on seotud originaalsuse kriteerium: loomeuurimus peaks andma uusi kaemusi, vorme, tehnikaid, kogemusi. Teadmise ja mõistmise juures rõhutab Borgdorff, et teema tajumine ja tunnetamine on loomeuurimuse puhul sageli olulisem selle selgitamisest 
ja seletamisest. Hüpoteesidest ja täpselt sõnastatud uurimisküsimustest tähtsamaks peab ta "kunstniku vaikivaid mõistmisi (tacit understandings), kogemusi, asjatundlikkust ja tundeerksust varem kaardistamata territooriumi avastamisel" (ibid.: 164; vrd Grimshaw \& Ravetz 2015). Kunstilised praktikad on kontekstisidusad ning loomeuurimus peaks tõestama oma aktuaalsust nii kunstimaailmale kui teadusele. Borgdorff rõhutab mitmel puhul, ka meetoditega seoses, et "kunstiline tegevus on ülimuslik loomeuurimuse teema, meetodi, konteksti ja tulemuste suhtes" (ibid.: 146), nimelt see eristab loomeuurimust sotsiaalteadustest või empiirilisest kultuuriuurimisest (ibid.: 166). Kaemused ja uued teadmised sünnivad just loomeprotsessis. Teadusega käib üldjuhul kaasas nõue tööprotsessi dokumenteerida ja jagada ning siingi tuleks Borgdorffi arvates leida lahendus, mis veenaks nii kunsti- kui ka teadusmaailma esindajaid (vrd Siegenthaler 2013).

\section{Defineerimatu loome}

Borgdorff on filosoofia ja muusikateooria taustaga ning ise ta kunsti ei tee. Geofüüsikat ja filosoofiat õppinud kunstnik Florian Dombois kirjutas 2006. aastal "kunsti kui uurimise" (Kunst als Forschung/art as research) teemal kümnepunktilise manifesti, mis keskendus vähem formaalsetele kriteeriumidele ning rohkem kunsti autonoomiale ja iseväärtusele (Dombois 2006; Dombois \& Hilt-brunner 2019). Tänaseks on Dombois kunsti kui uurimise või loomeuurimuse mõistest lahti öelnud. Uurimistöö (research) on tema nägemuses iga distsipliini või eriala lahutamatu osa, mitte teaduse (science) privileeg või sünonüüm ning kunstnikel peaks olema õigus oma arusaama uurimisest ise määratleda. Näiteks ei peaks uurimus kunstis tingimata sisaldama sõnalist komponenti, mis praegu kipub mitte-verbaalse endale allutama (Dombois 2017; Dombois \& Hiltbrunner 2019). Ent kunstist üksi ei piisa (vrd Jaschik 2018 ja Jackson et al. 2019: 111 sotsioloogi ja folkloristi Gary Alan Fine’i uurimistöö kohta sel teemal).

Loomeuurimuse kategooria kujunemine näib olevat kasvatanud kunsti kohta ja võib-olla ka kunsti tarbeks tehtava uurimistöö mahtu, kuid uurijad ei ole alati kunstnikud. Loomeuurimusest eraldi "korraliku distsipliini" kujundajad, kes sageli ei olegi ise kunstnikud, soovivad Dombois' nägemuses kunsti distsiplineerida ja raamidesse suruda, kuid "kes kunsti taltsutab, kaotab selle" (Dombois 2017: 75). Sarnaselt on ta kriitiline nende suhtes, kes rõhutavad loomeuurimuse panust teadmisloomesse ja selle kaudu kunsti õpetlikkust, sest see tähendab, et kunst peab oma eksistentsi õigustama ja välja teenima. Kas 
"Kunst on tähtis, sest ta uurib" või "Kunst on tähtis. Kunst võib teha uurimistööd”, sedastab Dombois (ibid.: 76-77). Kunstilt teadlikku ja eesmärgipärast teadmisloomesse panustamist nõudes sekkutakse loomeprotsessi. Näiteks enda kohta ütleb Dombois: "saan edukalt luua ainult siis, kui ma olen unustanud, kui ma ei tea, kuidas; kui ma ei tea midagi!" (ibid.: 77). Samas oleks Dombois' arvates oluline, et kunstnikud ise oma nägemuse järgi kunsti ja kunstis tehtavat uurimistööd edasi arendaksid ning et neil oleks võimalus teha seda kunstiturust sõltumatult (ibid.: 78) - ja ilmselt ka teaduspoliitika mõjusfäärist väljaspool.

Dombois' kriitika haakub meediakunsti ja kultuuriuurija haridusega Rosanne van Klavereni (2014) kogemustega. Enda sõnul tunneb polaaralade rahvaste ja kultuuridega tegelev van Klaveren end kunstnikuna teadlaste seas nagu hunt lambanahas. Ta on nende seltsi palutud, aga mitte päriselt oodatud või kampa võetud. Van Klavereni arusaama kohaselt on hunt metsik ja tema teadmised intuitiivsed, sõnulseletamatud, samas kui (lääne) akadeemiline teadmine on kodustatud ja konventsioonide kammitsais. Van Klaveren arutlebki, kas ja mil määral peaksid kunstnikud end teadusmaailma normide ja ootustega sobitama ning millal on juba tegemist alistumisega (vrd Grimshaw et al. 2010) - või vaigistamisega?

Põhjalikumalt kunsti ning loodus- ja tehnikateaduste vahekorra uurimisega tegelenud Ruth Benschop (2020) leiab, et loomeuurimuse defineerimisest viljakam oleks vaadata, mida loomeuurimuse viljelejad teevad, ning arendada keelt, mis võimaldaks nende tööst ja selle tulemustest kõnelda. Võib-olla mitte päris ootamatult, kuid veidi ootamatul viisil pöördub ta sobivate sõnade leidmiseks etnograafiliste meetodite poole. Nimelt loeb ta sotsioloogia taustaga Stefan Hirschaueri (2006) etnograafilist kirjatööd sotsiaalse reaalsuse mitteverbaalsest või vaikivast dimensioonist - sellest, mis on hääletu, keelele eelnev, kirjeldamatu, sõnulseletamatu -, justkui oleks tegemist loomeuurimusega ning käsitleb kunstnik Pilvi Takala teoseid etnograafiana. Benschop (2020) pakub välja, et sarnaselt etnograafile võiks uurijast kunstnik arendada end tundlikuks instrumendiks, kes reflekteerib nii ennast kui ka maailma enda ümber, enda mõju sellele, ning häälestab end vastavalt olukorrale ja vajadusele ümber. Nii etnograaf kui kunstnik näitavad tuttavat tundmatuna, katkestavad vaikuse, mis sageli ümbritseb tavalist, oma näilises loomulikkuses tumma ja nähtamatut. Benschop leiabki, et "vaikuse uurimine moodustab loomeuurimuse tuuma ning üksnes vaikuse intensiivse ja üksikasjaliku uurimise läbi saab loomeuurimus hakata mõtisklema selle üle, mis on kunst, mida pidada teadmiseks ning kuidas teadmist luua ja maksma panna" (ibid.: 57). 


\section{Seletamise paine}

Dombois'le viidates võiks küsida, kes sedalaadi refleksiooni vajab - kelle töö või karjäär sõltub võimest vaikivat teadmist (tacit knowing) või teadlikkust (tacit knowledge) (Polanyi 1962; vt ka Siukonen 2016) sõnadesse panna? Kas teadmiseta, mida loomeuurimuse tegija teeb, on tema tegevus vähem kunstiline ja selle tulemus vähem kunst? Kas sellel on vaatajatele vähem pakkuda? Borgdorffi juurde tagasi tulles: kaardistades loomeuurimuse vahekorda erinevate teadusvaldkondadega, viitab ta ka etnograafilisele uurimistööle, mida tema sõnul ühendab loomeuurimusega arusaam välitöö subjektide ja objektide tihedast seotusest (Borgdorff 2012: 155). Teisal (ibid.: 157) märgib ta, et piir loomeuurimuse, etnograafia ja performance'i uurimise vahel näib tehislik ning praktikas on tegemist pigem kontiinumiga, mis toetab meetodite paljusust kunstniku töös. Kui kunstiline tegevus on sealjuures kõige muu suhtes ülimuslik ja samas peab uurimus kunstis veenma kunstnike ja kriitikute kõrval ka teadlasi, siis mida see tegelikult tähendab? Kas näiteks etnograafilisi meetodeid kasutava ja empiirilisest kultuuriuurimisest innustunud kunstniku tegevus peaks veenma ka antropolooge, etnolooge või folkloriste - või neid, keda on teostel kujutatud või kellelt inspiratsiooni ammutatud? Või tuleb viimastel eetiliselt küsitava, kuid visuaalselt mõjuva teosega silmitsi seistes vaikida? Milline on sellises olukorras dialoogi võimalus ja mõte?

USA folklorist Jason Jackson on kirjeldanud kummastust, mida ta koges, kui tema materiaalse kultuuri teooriate kursusel osalesid kunstiüliõpilased ja hiljem omakorda nende kaitsmiskomisjonides osaledes kohtas ta "loengus käsitletud teemasid pööraselt teisenenud kujul” (Jackson et al. 2019: 113). Enda sõnul tundis ta end kalliskivide või maagi maardlana või "turistide vaatamisväärsuse või tehasena, mis töötleb kompleksse sotsiaalteaduse mitte nii kompleksseks kunstiks". Jackson ei ütle, et see oleks halb, vaid et tegemist oli tema jaoks uue kogemusega (ibid.). Oma pigem napi kunstialastes kaitsmiskomisjonides osalemise põhjalt lisaksin, et ülesanne mõisteid ja teooriaid ning kunstilist väljundit tervikuks vormida ei ole kergete killast. Võõrad sõnad tuleb omaks teha, et need müra ei tekitaks, ja alati ei pruugi see õnnestuda või pole selle järele tegelikult vajadustki. Tekst ütleb üht, kuid looming mõtleb ja kõneleb midagi muud.

Ootamatultki on eelpool käsitletud küsimused kunstnikust kui etnograafist ning Teise kujutamisest ja teisestamisest jälle väga lähedal. Seminooli, muscogee ja diné/navaho päritolu kunstnik Hulleah J. Tsinhnahjinnie küsib oma loomingus "Millal ütleb foto rohkem kui sada sõna?" (nt Tsinhnahjinnie 2020 [1998]; vt ka Lippard 2010). Tsinhnahjinnie väitel on suur vahe, kas kaamerat hoiavad valged või pruunid käed. Vanad fotod Ameerika põlisrahvaste 
esindajatest, Tsinhnahjinnie esivanematest, kõnelevad ametlikku ehk inglise keelt, mistõttu nende sadadest sõnadest tema arvates ei piisa. Teisalt on ta aja jooksul õppinud neid pilte vaatama nii, et need kõnelevad temaga otse. Ta on omandanud oskuse vaadata võõraste poolt pildile jäädvustatud stereotüüpide taha ning näha seda, mida pildistajad ei näinud ega võinud väljast tulijatena teadagi. Sealjuures kirjeldab ta unenägude rolli selle mõistmise kujunemisel: masendav foto tapetud indiaanipealikust muutub lootusekiireks, kui unes võtab surnul käest kinni väike laps ja viib ta kaadrist minema (Tsinhnahjinnie 2020 [1998]).

Kuigi erinevalt, näitavad Benschopi ja Tsinhnahjinnie kirjutised, kuidas autori "ettekavatsetud soov" (Borgdorff 2012) teose mõju ja kasutuse ning loomeuurimusliku panuse üle üheselt ei otsusta. Ka anastajate dokumentaalfoto massimõrva ohvritest või teadlase kirjatöö on potentsiaalselt ammendamatu. Vaevalt mõtles Hirschauer lugupeetavasse teadusajakirja vaikusest kirjutades sellele, et keegi, näiteks Benschop, võiks lugeda tema artiklit loomeuurimusena, leidmaks sõnavara selle kirjeldamiseks, mida kunstipõhise uurimise praktikud teevad. Ka väga tundlik ja põhjalik autoetnograafiline kirjeldus sellest, mida autor teeb, ei seleta ära tema loomingut või selle kaudu loodavat, sellest ammutatavat teadmist (mis ei tähenda, et reflektsioon ei oleks oluline või ei mõjutaks töö kulgemist ja käiku). Kui uurimus kunstis on alati juba kunsti osa, mitte leiutamist vajav eraldi distsipliin (Dombois 2017: 76), võib loomepõhise uurimusena käsitleda ka neid teoseid, mis ei sündinud loomeuurimuslikest kavatsustest ja sündisid võib-olla hoopis enne seda, kui uurimine kunstis teoreetikute tähelepanu köitis. Kunstipõhine uurimus on ka vaataja silmades.

\section{Käsmu - Kärberi - Käsmu}

Praegu EKAs dotsendina töötav Eve Kask lõpetas Eesti Riikliku Kunstiinstituudi graafika osakonna raamatukujundajana 1984. aastal. Sarnaselt mitme teise graafikuga vahetas ta 1990. aastatel trükipressi fotograafia ja teiste tehnikate vastu, mis tähendas ka temaatilist nihet loomingus. Mütoloogiliste teemade ja linoollõigete poolest tuntud Kask asus tegelema Eesti ühiskonna, selle teisenemise ning siinsete inimeste ja nende püüdluste kaardistamise ja jäädvustamisega, kasutades selleks mh fotot, installatsiooni ja joonistust. Mitmel puhul on tal koos näitusega valminud loometööd populariseeriv ja jäädvustav autoriraamat (nt Kask 2008).

Eve Kase side Käsmuga ulatub tagasi lapsepõlve ning mitu aastakümmet tagasi rajas ta sinna ka kodu. Aastatel 1999-2003 pildistas ta veel fotofilmile üles pea kõik Käsmu küla elanikud ja suure hulga suvitajaid, kokku üle 600 
inimese; lisaks hooneid. Pigem pretensioonitud, sundimatud fotod inimestest üksi või koos pereliikmetega koduses ümbruses ning vaated majadele. Ettevõtmine päädis raamatuga "Käsmu inimesed ja majad 1999-2003" (Kask 2003). Kakskümmend aastat hiljem läks kunstnik uuele ringile ning mullu ilmus "Käsmu inimesed ja majad II. 2013-2019" (Kask 2019). Pildistamise kõrvalt kogus, jäädvustas ja süstematiseeris kunstnik andmeid, suhtles, tegi intervjuusid ning töötas arhiivides. Mõlemas raamatus on mustvalgete fotode juurde lisatud pildistatute nimed, sünni- ning mõnel puhul ka surmaaeg ja -koht, Käsmus veedetud aja pikkus; teise raamatusse on lisatud ametid või tegevusvaldkonnad. Samuti leiab raamatutest hoonete "biograafia": ehitusaasta, olulisema(te) ümberehitus(t)e daatumid, võimalusel arhitekti nime, selgitusi hoone varasemate funktsioonide kohta. Samas on fotod vaadeldavad ja toimivad ka ilma metaandmeteta. Portreed on olnud 1999. aastast eksponeeritud Käsmu Dellingshauseni kabelis, kus kunstnik on väljapanekut jooksvalt uuendanud, ning vähemalt "Käsmu inimeste" esimene seeria on edukalt Euroopas näitustel ringi rännanud.

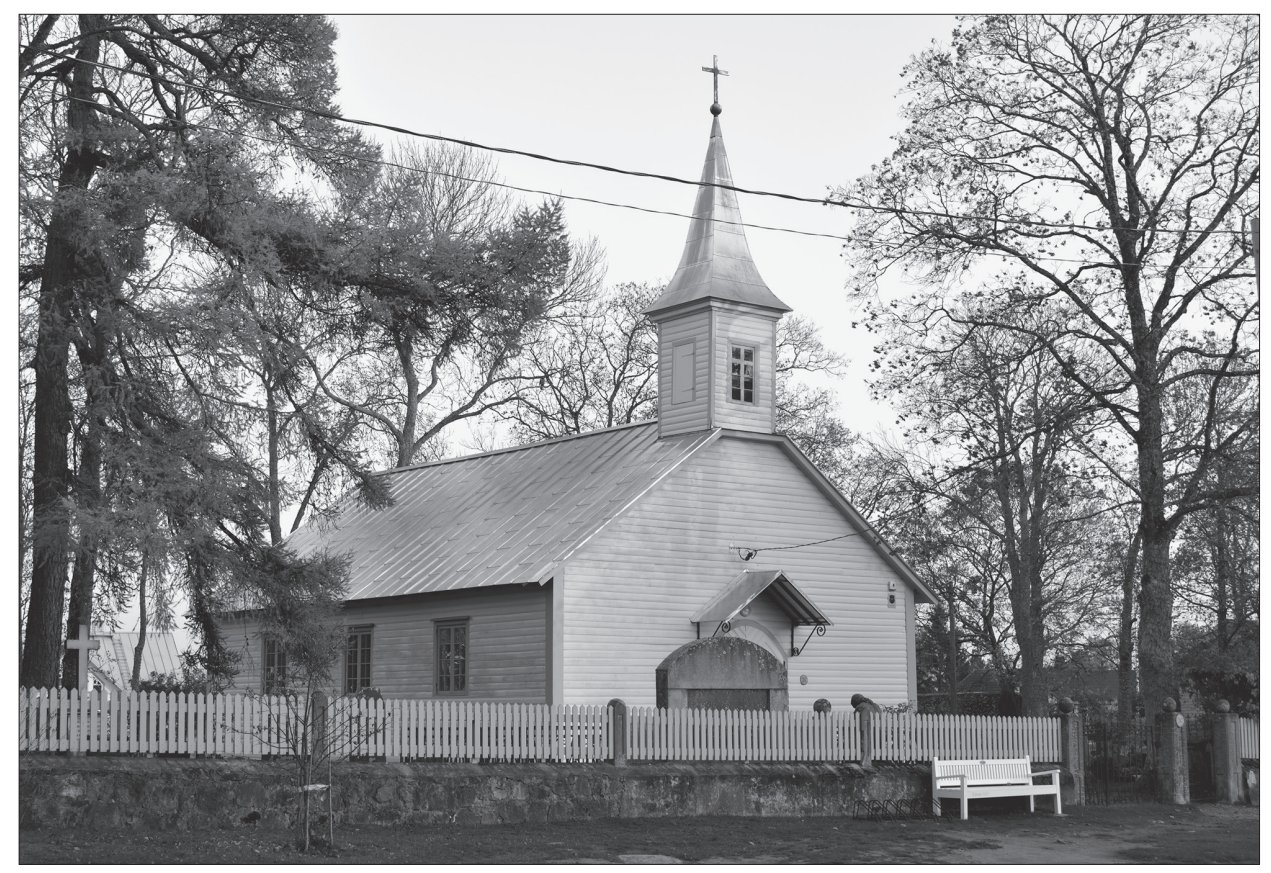

Foto 1. Käsmu kirik oktoobris 2018. Kirik on ehitatud 1863, pühitsetud aasta hiljem ning on kolmas pühakoda samal kohal. Eve Kase foto. 


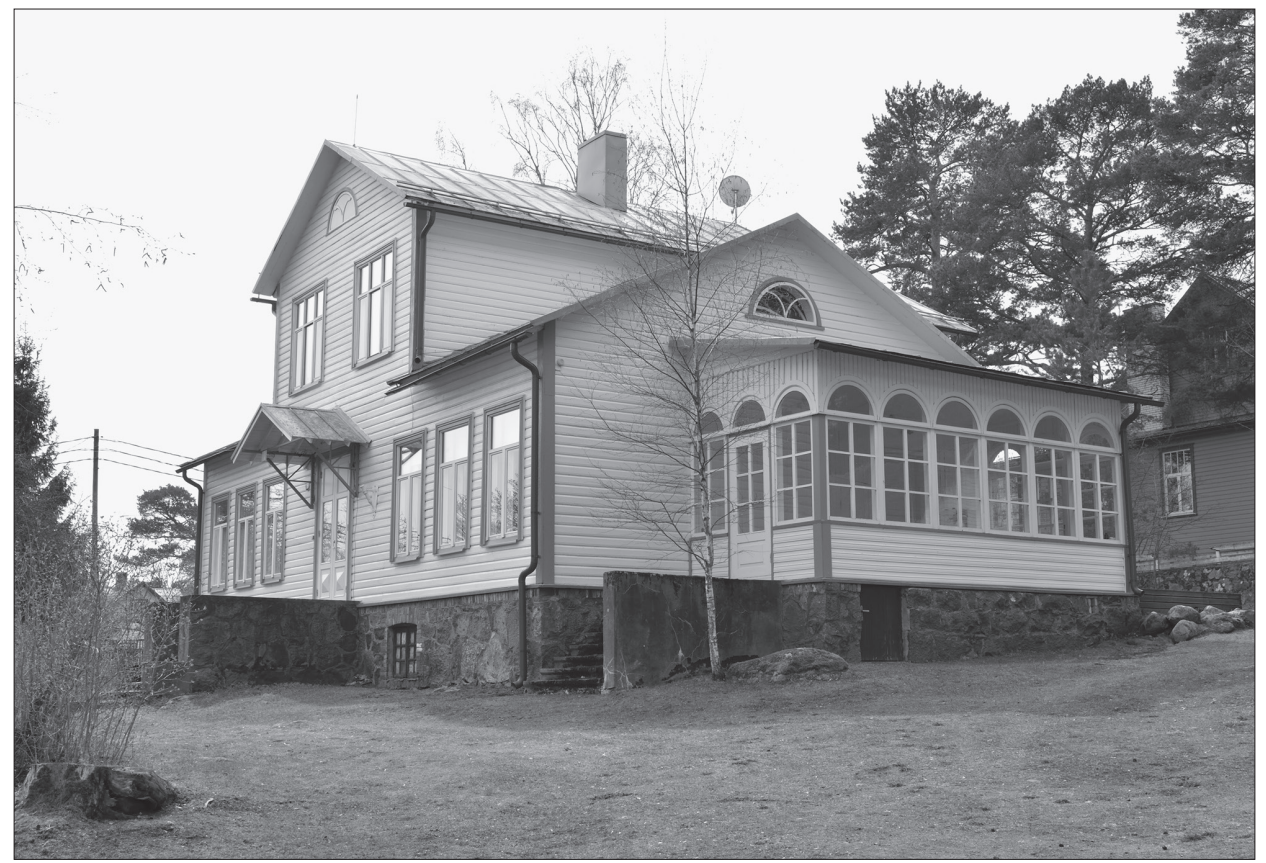

Foto 2. Hiie maja (Käsmu) aprillis 2019. Hoone ehitust alustati 1914 ja see valmis 1920. aastatel. Nõukogude ajal üks ETKVLi puhkekodudest, 1997. aastast Eesti Kirjanike Liidu hallatav kirjanike ja tõlkijate loomemaja. Eve Kase foto.

Paksu metsa ja mere vahele surutud väikse Käsmuga on kerge samastuda, nii kunstnikul kui portreteeritavatel. "Kuna Käsmu on silmatorkavalt ilus koht, siis inimesed meelsasti seostavad end just kohaga”, märgib Kask (2004). Suvituskultuur Käsmus ulatub sajandite taha ning eriti Nõukogude perioodil kujunes sellest vene haritlaste ja loomeinimeste üks lemmik-suvituspaiku; nii mõnelgi talul olid oma "Moskva suvitajad". Osa neist on leidnud nüüd uuesti tee Käsmu. Käsmus asub Kirjanike Liidu loomemaja, seal suvitab või elab üksjagu kultuuritegelasi. Kohaspetsiifiline kunstiprojekt Käsmus ja Käsmust ei üllata, kuid Kase ettevõtmine on aastate jooksul sulandunud kohaliku elu osaks ja mälukandjaks. Sellest on saanud kogukonda loov ja reflekteeriv, Käsmut nii sees- kui väljaspoolsetele representeeriv protsess, mis jätkub ka kunstnikust sõltumatult kabeli väljapaneku külastamise, raamatute lehitsemise ja kasutamise ning külalistele näitamise kaudu.

Eve Kase Tallinna kodu asub Lasnamäel, ruumikas ateljeekorteris, milliseid jagus Nõukogude ajal vähestele kunstiinimestele. Pärast esimese Käsmu raamatu valmimist otsustas ta ette võtta kõigi oma Lasnamäe naabrite pildistamise ning 2004 kevadel ja suvel sündis sari “Kärberi 37”. Aastal 1985 
valminud 72 korteriga üheksakorruseline paneelmaja asub linnaosa tagumises otsas, kunagise sõjaväelennuvälja serval. Veel hiljuti avanes Kase koduaknast vaade tühjale paesele väljale, nüüd on sinna kerkinud lahmakad ja hirmkallite korteritega uusarendused.

Oma märkmetes kirjeldab kunstnik majanaabrite pildistamist “"kestast” välja pugemisena" (Kask 2004). Vajadus selle järele kasvas välja Käsmu projektist - tundest, et “ilusat” Käsmut pildistades vaikib ta maha teise, Lasnamäe poole oma elust ja endast, ning et see on "ebaaus", nagu ta ühes intervjuus ütles. Samas mõjus just Lasnamäe vähemalt algusaastatel loomingulisele tegevusele hästi, sest väliskeskkonna armetus aitas koondada tähelepanu sisemaailmale. Nagu Käsmu seeria, nii ka Lasnamäe sari sisaldab fotot Eve Kase enda perest. Kaks teost kuuluvad kokku. Tervele külale maal vastab üks suur kortermaja linnas. Ühendavaks lüliks on kunstnik ja tema soov oma ümbruskonda dokumenteerida (vt ka Ladõnskaja \& Pavlenko 2007; Juske 2009), kuid teosed heidavad valgust ka Eesti ühiskonnale laiemalt ning jagatud kujutelmadele sellest, neid kujutlusi samal ajal luubi ja küsimuse alla seades.

\section{Olemine, kuulumine ja sekkumine}

Rände ja hargmaise elukorralduse uurijad (Levitt \& Glick Schiller 2004) on välja pakkunud eristuse olemise ja kuulumise viiside vahel (ways of being; ways of belonging). Olemise viisid tähistavad praktikaid, suhteid ja kategooriad, millega inimene oma elus tegelikult kokku puutub, mis teda puudutavad, aga millega ta ei pruugi samastuda. Kuulumise viisid seevastu väljendavad teadlikku kuulumist teatud kategooriasse. Eriti sisserändajad ja oma elu mitme koha vahel jagajad balansseerivad sageli kuulumise ja olemise vahel. Kui Käsmu raamat sündis kuulumise kogemusest ja väljendas seda, siis "Kärberi 37" sai tõuke tunnetatud lõhest kuulumise ja olemise vahel ning püüdis neid lepitada või lähendada. Kaudselt kutsus kunstnik ka pildistatavaid end oma kodumaja ja laiemalt Lasnamäe või Tallinna või Eesti suhtes positsioneerima. Käsmus tajus Kask, et pildistatavad on Käsmu valinud, et “(n)eid seob üks ja seesama koht” ning et "neil ei ole midagi selle nähtamatu sideme või solidaarsuse vastu - jagada ühte näituseruumi teiste külaelanikega" Dellingshauseni kabelis.

Paneelmajas on olukord vastupidine. See on saatus ja juhus, et just need konkreetsed inimesed on sattunud jagama tillukest territooriumi ja neil kas ei ole mingit soovi (osade pildistamisest keeldujate üks motiividest) seostada oma isikut ühe anonüümse paneelmajaga või on nad ükskõiksed või mõistmatud minu soovi suhtes pildistada ühe "ebahuvitava" maja kõiki inimesi. Ja tõesti ei seo neid midagi peale paneelide. 


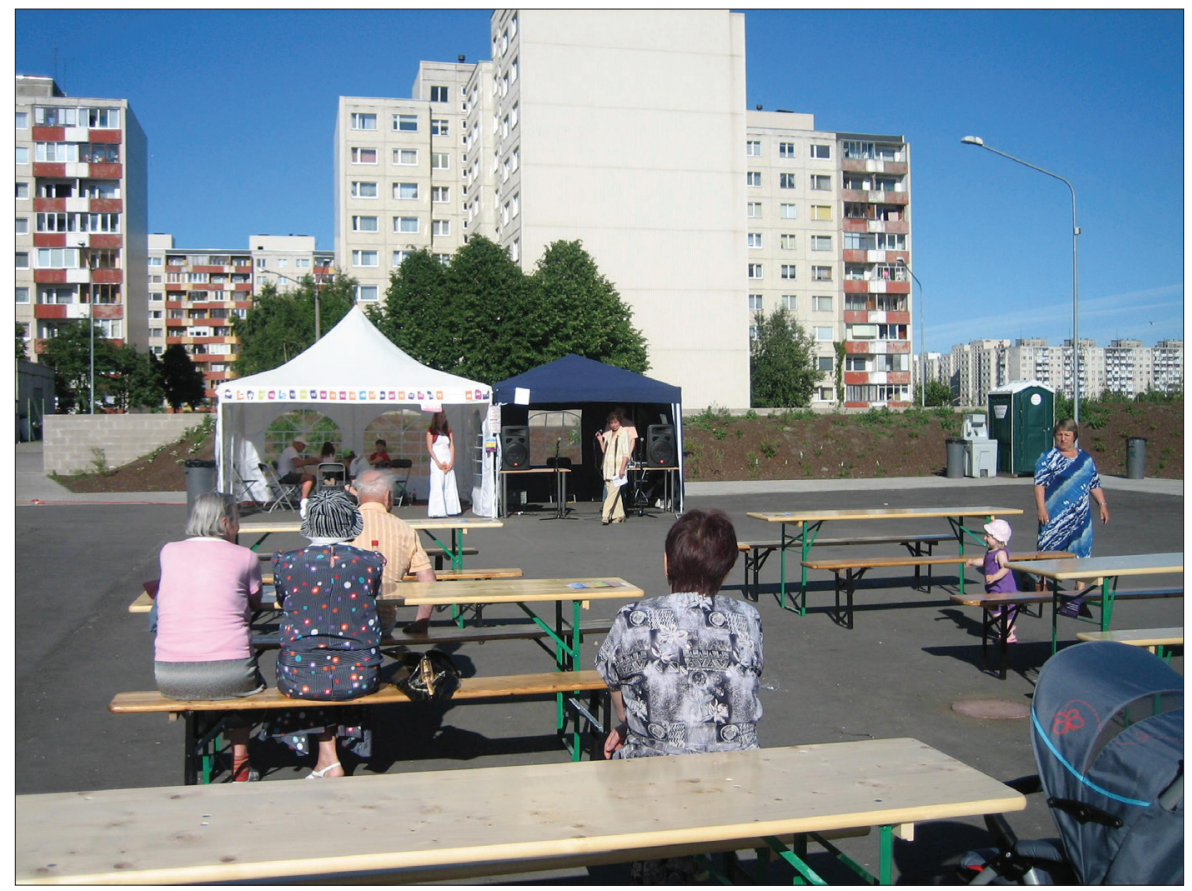

Foto 3. Isetegevuslikud etteasted koduse toidu laadal Lindakivi kultuurikeskuse ouel juulis 2010. Üritus pidanuks idee poolest kokku tooma lasnamäelased ja Tallinna teiste linnaosade elanikud, ent tegelik huvi jäi kasinaks nii potentsiaalsetel võõrustajatel kui ka külalistel. Foto: Elo-Hanna Seljamaa.

Olin sellega arvestanud ja ka sellega, et mul ei oleks pruukinud üldse pildistamine õnnestuda (Kask 2004).

"Kestast välja pugemine" tähistas iseenda elu erinevatele tahkudele otsa vaatamist ja nendega tegelemist, ka teatavat eneseületust: "Terve aasta tõrjusin pildistamismõtet oma peas ebamugavustundest kõrvale" (ibid.). Lõpuks sundis tegutsema kutse Saksamaal näitusel esineda. Samaaegselt võtab kesta metafoor kokku suure kortermaja eluviisi (vt ka Ladõnskaja 2013: 43-44). Iga korter moodustab selle elanike ümber kaitsva kesta, kuhu ei ole sünnis tungida. Märksõnadeks on anonüümsus, läbikäimise puudumine ja seda ka olme sujuvuse huvides. See on jagatud pinnas, millest kortermaja argielu võrsub. Naabrite pildistamisteks tuli kunstnikul kõigepealt enda kestast välja murda ning seejärel torkida teisi majaelanikke, veenmaks neidki uksi paotama. Hinnanguliselt kaks kolmandikku kuni kolm neljandikku majaelanikest olid teisest rahvusest, peamiselt venelased, mis tähendas, et asju tuli ajada kahes keeles. Nagu minul, nii oli ka Kasel võimatu etnilist tõlgendusraami mitte esile kutsuda ning etnilisuse pidevasse taastootmisesse mitte sekkuda (vrd Brubaker 
et al. 2006). Kask pani kõigile naabritele postkasti kakskeelse viisaka pöördumise, helistas uksekella ja koputas, lähenes majaelanikele trepikojas: tegi kõike seda, mida ta tavaolukorras ei teeks. Olemise ja kuulumise lepitamine nõudis kirjutamata reeglite ja vaikivate kokkulepete rikkumist - teiste ellu sekkumist, ka konfliktiga riskimist.

Märkmetes kirjeldab kunstnik erinevat tüüpi reaktsioone, mis tema pildistamissoovile osaks said, ning üheks neist oli “(r)äme sõim, väljaviskamine, sageli isegi ukse mitte avamine, soovimatus suhelda ja igasuguse huvi puudumine minu seletuste vastu" (Kask 2004). Keelduda võidi ka "argumenteeritud põhjustel" või siis nõustuda pika veenmise tulemusena, kuid ilma et kunstniku motiivid nõustujat päriselt veennud oleksid (ibid.). Kokkuvõttes jäid portreteerimata 23 korteri elanikud. Mõnele maja ees või koridoris kohatud juba pildistatud naabrile lähenes kunstnik veel teistki korda, sest väljaspool koduseinu "olid nad nii anonüümsed, et sa ei tunne neid ära".

Ühe erandiga on Kärberi tänava majas inimesi pildistatud nende endi kodudes, mitte trepikojas, liftis, maja ees tänaval või muus ühiskondlikus ruumis,

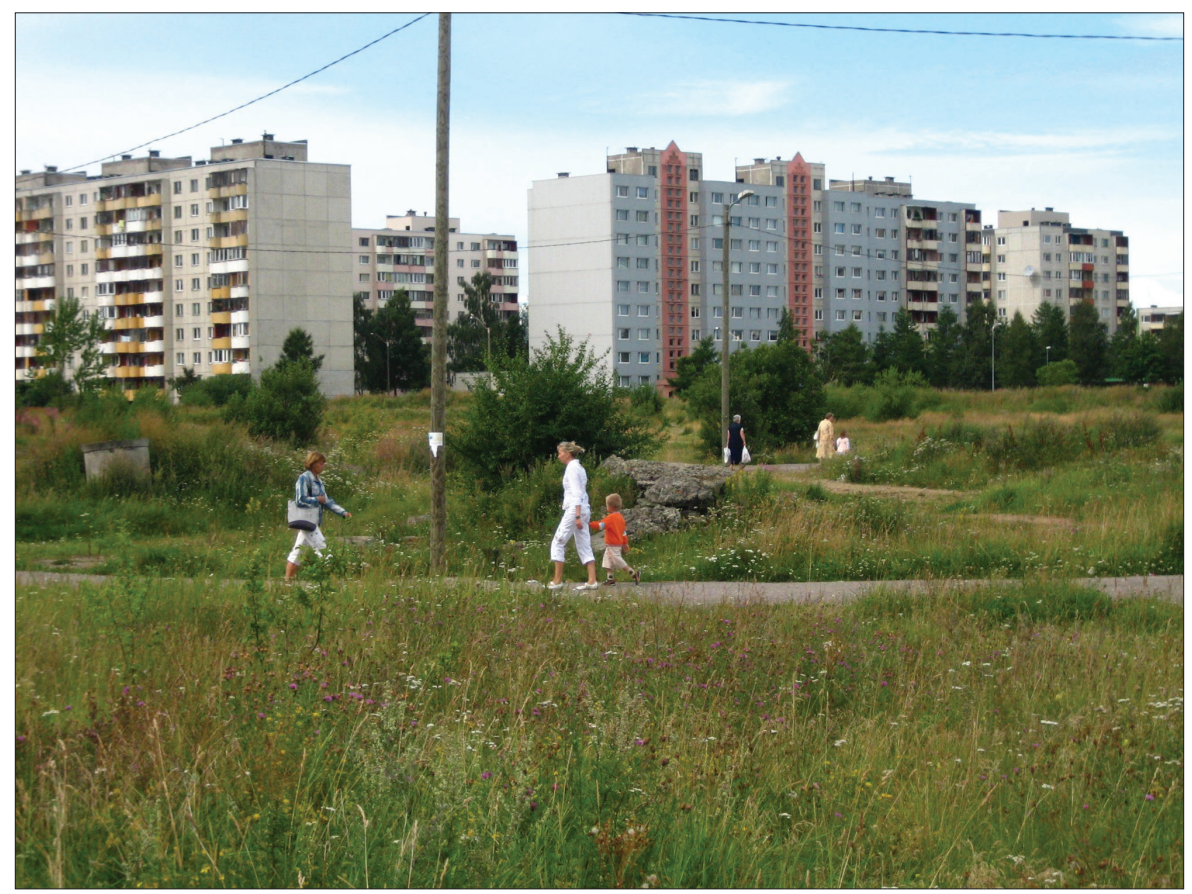

Foto 4. Vaade suvisele Lasnamäele augustis 2009. Majad paiknevad kobaras ja kobarate vahel laiub tänini mitmel pool tühermaa, mis on täis kohalike tallatud radasid ning kust leiab tuleasemeid ja muid argiste tegevuste jälgi. Foto: EloHanna Seljamaa. 
kus tavaolukorras naabritega kõige loomulikumalt ja sagedamini kokku võidakse puutuda. Pildistamise taustaks vesteldi, ja siingi kogus Kask andmeid naabrite elukäigu kohta. Vestlused ja andmete kogumine oli osa taustatööst, aga ka viis portreteerivate avamiseks, nende pealiskaudseltki tundma õppimiseks. See koos veedetud aeg on talletatud fotodesse ja vaikimisi osa nende esteetikast. Kui Kasega 15 aastat hiljem koos Lasnamäe materjale sirvisime, olid tal mitmed elusaatused ja lood jätkuvalt meeles.

Ka mängis ta minuga ühte mängu, mida mäletan oma lapsepõlvest 1980. aastate lõpust. Kunstnik palus mul fotosid vaadates ära arvata, kas tegemist oli eesti või vene või mõnest muust rahvusest isiku või perega. Mõnel puhul läks mu arvamus täkkesse, teinekord mitte ja mõnikord, nagu vestluse salvestust üle kuulates meenus, oli meile mõlemale sõnadetagi selge, kellega tegemist. Ainult jutu põhjal, fotosid nägemata, pole tagantjärele alati võimalik tuvastada, miks oli mõlemale "kohe näha", et tegemist oli eestlaste või venelastega. Meil olid varnast võtta jagatud tõlgenduslikud raamid, mille abil pildistatuid essentsialistlikult kategoriseerida (Brubaker et al. 2006). Kask tegi iga korteri

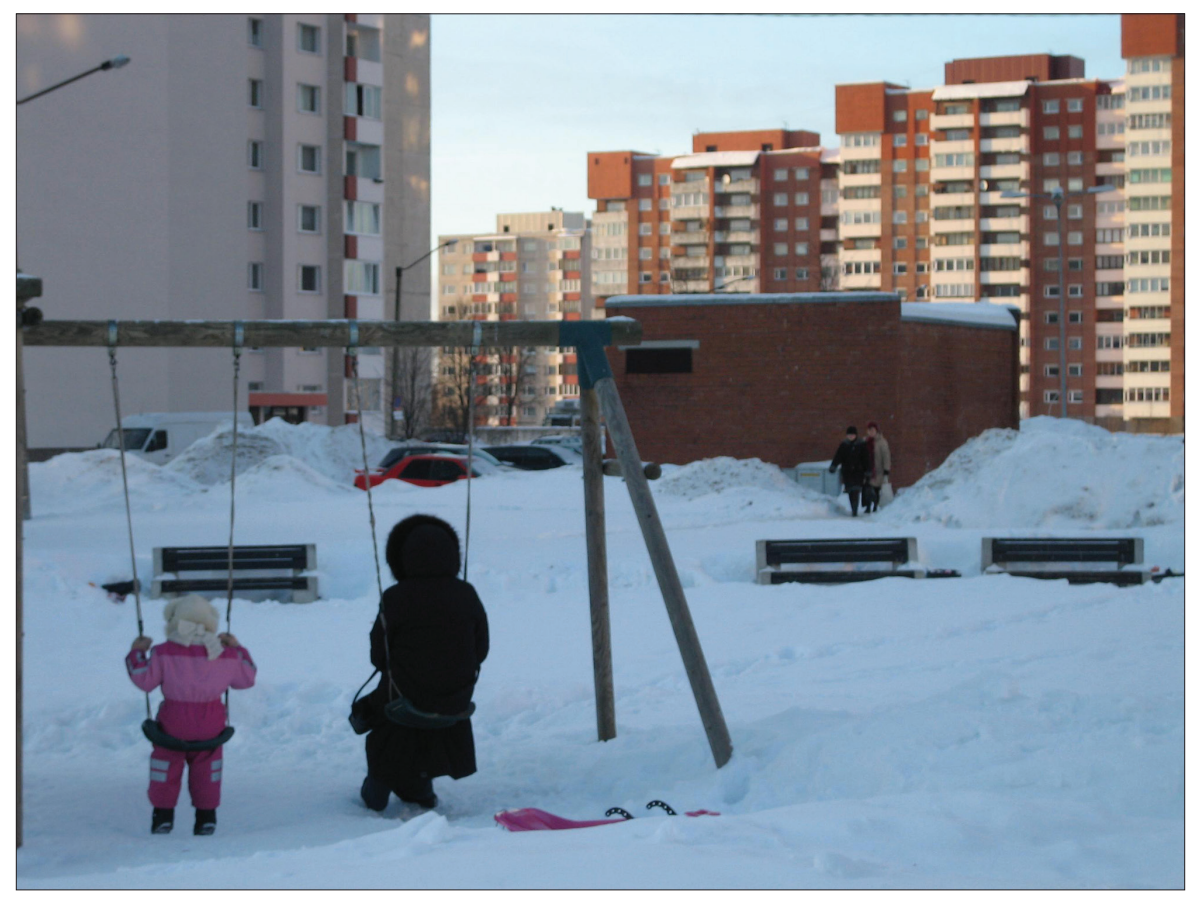

Foto 5. Mänguplats majade vahel Laagna tee ehk Lasnamäe kanali lähedal veebruaris 2010. Foto: Elo-Hanna Seljamaa. 
elanikest mitu fotot ning vähemalt ühel juhul mainis ta intervjuus, et valis eksponeerimiseks välja selle pildi, mille muutis "eestlaslikuks" õlekompositsioonist kaunistus pildistatute taustal.

Oma välitöödest teadsin, et välimus on (juba ammu) petlik - rääkimata etnilise ja igasuguse muu kuuluvuse mitmetahulisusest ja kontekstisidususest (vt ka Hatšaturjan 2012 noorte eestivene haritlaste voolava lapiteki-identiteedi kohta). Ometi või just selle pärast osutas meie mäng sellele, kuidas "Kärberi 37" sekkus mitte ainult pildistatute ellu, vaid ka fotode vaatajate, sh meie endi, (eel) arvamustesse ja uskumustesse Lasnamäe, eestlaste ja venelaste kohta - harjumuspärastesse teisestamise ja etnilisuse (taas)loome praktikatesse. Võimaluse mängimiseks avas teose vorm (vrd Grimshaw \& Ravetz 2015) - üksteisele järgnevad ühetaolised, sama käekirjaga fotod, mis justkui kutsuvad mõistatama ja teevad sealsamas vahetegemine keeruliseks ja lõpuks mõttetuks. Välismaise vaataja silmis - ja selle sarjaga on Kask esinenud pigem väljaspool Eestit jooksevad piirid aga sootuks mujal (vrd Tsinhnahjinnie 2020 [1998]). ${ }^{7}$

Eestis on "Kärberi 37" seni väljas olnud vaid ühe korra, 2009. aastal Tallinna Kunstihoone toimunud näitusel "Eesti nägu" (Juske 2009), mida vaatama kutsus kunstnik ka majanaabreid. Intervjuus rääkis ta, et pärast sisemise barjääri ületamist ja pildistamiseni jõudmist püüdis ta asetada end oma majanaabrite olukorda, eeldades, et nad pigem ei soovi, et nende portreid eksponeeritaks. Välismaal võimendab geograafiline distants Lasnamäe elukeskkonnaga seostuvat anonüümsust, samas kodumaal sulab see vahemaa väiksemaks ning toob kaasa tugevama enesetsensuuri. Eetika ja esteetika suhe on pingeline, eriti kui kaalul on loomevabadus (vrd Grimshaw \& Ravetz 2015). Näiteks folkloristikas on otsitud võimalusi uuritavate kaasamiseks, katsetatud dialoogilise või vastastikkusel põhineva etnograafiaga (nt Lawless 1992), aga ka kaheldud selle teostatavuses (vt Mullen 2000; Truvillion 2000 jt artiklid samas erinumbris). Näib, et kunstis tõstatuvad tegija vabaduse küsimused komplekssemal ja eksistentsiaalsemal moel ning seda isegi n-ö kogukonnakunsti puhul, mil kunstitegemise eesmärgiks on kaasata ja väestada (vt nt Triisberg 2016 Vao Keskusesse majutatud varjupaigataotlejatele suunatud kunstiprojekti kohta).

Kui Käsmu inimeste pildistamine on osutunud kogukonda loovaks viisidel ja määral, mida kunstnik ei võinud ette planeerida ja liiatigi taotleda, siis "Kärberi 37" tegemise ja senise eksponeerimise lugu on kulgenud teistes tingimustes. Kask küll suhtles mõnda aega pärast pildistamist mõnede majanaabritega edasi, kuid aegamisi kasvasid kestad jälle jäigemaks ja kinni. Olemise ja kuulumise viiside sulam jäi üürikeseks (vrd Levitt \& Glick Schiller 2004). Meie vestlustes kasutas ta korduvalt planeedi metafoori, märkides näiteks, et pildistatud inimesed elavad eri planeetidel sama õnnelikult edasi kui enne seda projekti. Kujund viitas elukeskkonna anonüümsusele ja suhtlemise 
puudumisele üldiselt, aga oli ka etniliselt markeeritud: üks venekeelsetest naabritest kutsus teda Lindakivi kultuurikeskuses toimunud kontserdile, mis tekitas tunde, justkui oleks ta "teisele planeedile sattunud". 8

\section{Tagasi visuaalide ja sõnade juurde}

Kuigi väliselt on Käsmu ja Kärberi fotod sarnased, teostatud samu põhimõtteid järgides, jääb Lasnamäe fotodest vähemalt mulle intiimsem mulje ning minu silmis on selle näol tegemist isiklikuma projektiga. Võimalik, et see mulje on tingitud sellest, et olles samuti istunud võõraste inimeste kodudes Lasnamäel, suudan ma nende fotode tegemise protsessiga vahetumalt samastuda. Samas mina ei ole pärit Lasnamäelt ega ela seal. Välitöid tehes oli see minu jaoks olemise, töötamise koht, kust ma hiljemalt õhtul läksin tagasi oma linnaossa

Foto 6. Kakskeelne Lasnamäe augustis 2009. Foto: Elo-Hanna Seljamaa.

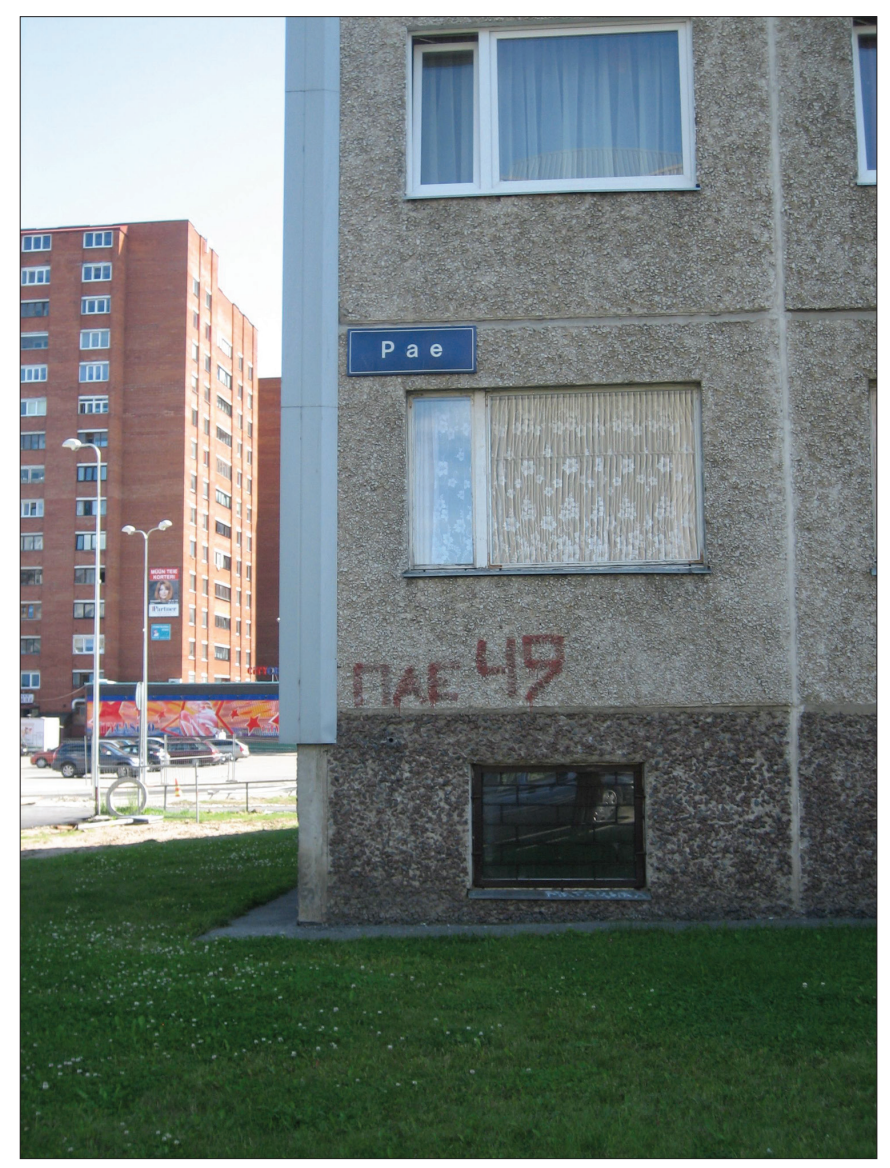


ja samuti kakskeelsesse, kuigi palju vanemasse kortermajja. Sellisena oli minu ettevõtmine Lasnamäel veelgi otsesem ja võib-olla räigem sekkumine. Ma ei saanud küll kordagi sõimu osaliseks, kuid kohtasin üksjagu umbusku ja eitavaid vastuseid ning ka üllatunud-küsivaid pilke. Üks Lasnamäe juuksur küsis minult väga otsekoheselt, kuigi sõbralikult: “Как вы сюда попали?" Teravad situatsioonid, mida olen tunnistama sattunud või milles olen ise argiselt osalenud kas Lasnamäel või mujal, on keerelnud keele ümber: puhkenud ootusest, et kasutama peaks (ka) vene keelt või et asju peaks saama ajada eesti keeles (Seljamaa 2016).

Nende episoodidega seotud ebamugavad, aga ka meeldivad emotsioonid on olnud mulle teoorialoome allikas. Samas püüan välitöödel põhinevas teadustöös sekkumist minimiseerida, mh selle kaudu, et annan oma vestluspartneritele uued nimed, ei avalda nende kodutänava nime ja liiati majanumbrit, vahel olen jätnud täpsustamata ka sugupoole. Kõigi nende abinõude kõrval tundubki Eve Kase portreesari julge ja paljastav. Kontrast on seda suurem, et "Kärberi 37" fotode valmimise protsess meenutab mulle minu etnograafilisi välitöid, ka selles osas, et me mõlemad sõltusime otsustaval moel kaasinimeste heatahtlikust huvist ja armust või lihtsalt vastutulelikkusest. Kase "kestast välja pugemise" kirjeldused ja kogemused ning selle seisundi ajutisus kinnitavad minu silmis minu oma kogemusi ja nende põhjal tehtud järeldusi selle kohta, kuidas pealinna eesti- ja venekeelsed elanikud argiselt linnaruumi jagavad ja selles oma väiksemaid ruume loovad, kuidas etnilisust ei saa uurida kaude.

Aga kui mina püüdsin välitöid tehes jõuda küllastumispunktini, olukorda, kus uus informatsioon hakkaks olemasolevat kordama ja kinnitama, siis Kask taotles ammendatust tema enda seatud raamide piires ja kunstilisest visioonist juhituna. Kase fotosarja lähtekoht oli ka isiklikum mind Lasnamäele ja etnilisuse uurimiseni toonud põhjustest. Tema loomeprotsess oli pidev ja läbiv, veelgi raskemini etappideks jagatav kui seda on välitööd ja analüüs empiirilises kultuuriuurimises. Loomeprotsessi tulemusena sündinud fotod dokumenteerivad ühe Lasnamäe kortermaja elanikke 2004. aasta seisuga viisil või vormis, mis seab vaatajad vastamisi nende endi kujutelmadega linnaosast ja selle elanikest, rahvusest, tänapäeva Eestist. Milline tahk esiplaanile tõuseb, sõltub ka fotode eksponeerimise kontekstist. Konventsionaalsete teaduslike (enese)väljendusvahendite abil saab äraarvamismänge kirjeldada, kuid mitte mängida. Uurijad leiutavad järjest uusi termineid, tabamaks näiteks rände ja etnilisuse ning nendega seotud kogemuste ja seisundite mitmesust. Neid sõnu on vaja, ja neist juba jälle või kunagi ei piisa, nagu mõnes muus olukorras ei piisa kunsti suurest üldistusjõust ja võimest nihestada tuttavaks peetut ning rääkida meist igaühega eraldi ja sõnatult. Ometi võiks julgustada koostööd nende kahe maailma vahel, ka selleks, et enda piirjooned selgemaks saaksid ning kunstipõhise uurimuse võimalused kuuldavamaks ja nähtavamaks muutuksid. 


\section{Tänuavaldused}

Artikkel valmis Eesti Teadusagentuuri projekti PSG48 "Folkloristlik vaade kuulumisele ja mitte-kuulumisele Eestis" toel ning Eesti Kunstiakadeemia rahastatava loomegrandi raames; tulemuste saamiseks tehtud teadustööd on rahastatud ka EMP finantsmehhanismi Balti teaduskoostöö programmist. Soovin tänada Eve Kaske ning Käsmu teemalises loomegrandis osalevaid ja osalenud üliõpilasi ja kunstnikke, Liina Siibi ja Eha Komissarovit ning Pihla Maria Siimu ja Anastasiya Astapovat huvitavate mõttevahetuste eest. Olen tänulik erinumbri toimetajale Reet Hiiemäele vastutulelikkuse ja sisuka tagasiside eest ning tänan ka anonüümset retsensenti asjakohaste ja innustavate kommentaaride eest.

\section{Kommentaarid}

1 Näiteks tulevad meelde Flo Kasearu, Tanja Muravskaja, Kristina Norman, Silja Saarepuu ja Villu Plink, Eva Sepping, Liina Siib, aga nimekiri on kindlasti pikem.

2 Rahvusvaheliselt kasutatakse ka termineid praktikapõhine (practice-based) ja praktikast juhinduv (practice-led) uurimine. Kolleegid Tartu Ülikooli Viljandi kultuuriakadeemia rahvusliku käsitöö osakonnast eelistavad rääkida praktikapõhisest uurimisest ja uurimismeetoditest, pannes rõhku käsitöötehnikate tundmaõppimisele kui uurimistöö eeldusele (vt nt Jackson et al. 2019: 112).

3 Ammuste tuttavatena oleme Eve Kasega teinud viimastel aastatel koostööd EKA rahastatud loomeuurimusliku grandi raames, mis kombineerib kaasaegse kunsti ja empiirilise kultuuriuurimise võimalusi ning julgustab erialade vahelist ja ülest koostööd. Projekti keskmes on Käsmu küla, kus 2019. aasta suvel toimusid Tallinna Ülikooli ja Tartu Ülikooli antropoloogia, etnoloogia ja folkloristika üliõpilaste ning EKA üliõpilaste ühised välitööd. Projekti üheks väljundiks oli näitus "Kuidas rääkida salapaigast seda reetmata" märtsis 2020 (Loor \& Orn 2020) ning uurimistöö ja näitusetegevus jätkub. Artiklis tuginen 2019. ja 2020. aastal salvestatud (27.12.2019 ja 02.05.2020) ja salvestamata vestlustele Kasega ning kunstniku käsikirjalistele materjalidele (Kask 2004), mida ta minuga lahkelt jagas.

${ }^{4}$ Eesti-vene segaperesid intervjueerinud Uku Lember on kirjutanud vaikusest ja vaigistamisest lähedaste vahel Nõukogude ajal. Etnokultuuriliste "(v)astuolude vähendamine oli tihtilugu praktiliseks lahenduseks segapere eluilma alalhoidmisel, eriti olukorras, kus diskursiivsed vahendid arutamiseks puudusid. Kuid see pole ebaloomulik toiming, pigem vastupidi - see on konstruktiivne ja põhineb tajul, et läbirääkimistesse asumine võib lõppeda krahhiga. Teisalt ja sama olulisena viitab etnokultuuriliste diskussioonide puudumine tihtilugu otseselt konfliktide puudumisele igapäevaelus. Inimesed elasid olukorras, milles nad kultuurimaailmade vahelisi pingeid oma elus ei tajunud" (Lember 2015).

5 Kasutan terminit 'empiiriline kultuuriuurimine' katusterminina, mille alla mahuvad nii folkloristika, etnoloogia kui ka antropoloogia, mis kõik põhinevad välitöödel ning kasutavad mitmeid kattuvaid või sarnaseid välitöömeetodeid. Rahvusvahelises kunsti ja etnograafiliste meetodite teemalises kirjanduses domineerib antropoloogia, 
kuid käsitletavad teemad ja probleemid võiksid tuttavad ette tulla ka folkloristidele ja etnoloogidele. Artikli fookusest jäävad välja visuaalantropoloogia ja kunstiantropoloogia, kuigi ühisosa mõlemaga on kindlasti suur ning kunsti ja etnograafiliste meetodite vahekorra üle peetavas diskussioonis osalevad ka nende uurimissuundade esindajad (vt nt Kisin \& Myers 2019). Samuti ei ole siinkohal võimalik süveneda kogukonnakunsti temaatikasse.

${ }^{6}$ Loomeuurimuse kujunemine ning institutsionaliseerimise võimatus ja võimalikkus jäävad selle artikli fookusest välja. Rahvusvahelistest arengutest annab üldise ülevaate nt Borgdorff et al. 2020: 3-5 ja põgusalt eesti keeles Pesti 2018; isiklikuma ja ka kriitilisema nägemuse leiab näiteks kunstnik Florian Dombois' intervjuust antropoloog Michael Hiltbrunnerile (Dombois \& Hiltbrunner 2019); Eesti kohta tagasivaatavalt Kelomees 2014.

7 Sari oli eksponeeritud 2005. aastal Berliini Kunstide Akadeemias seda perioodi hästi iseloomustava pealkirjaga näitusel "E.U. positiivne - kunst uuest Euroopast" (kuraatorid Eckhart Gillen ja Matthias Flügge). Samas, erinevalt kunstiprojektide suurest enamusest ületas “Kärberi 37" Eestis uudiskünnise. Vt Ladõnskaja \& Pavlenko 2007; Ladõnskaja 2013: 38-45.

8 Lasnamäega seostatud anonüümsust ja passiivsust püüab ületada ning positiivset kohatunnet tugevdada 2014. aastast tegutsev kakskeelne MTÜ Lasnaidee, mis korraldab piknikke, kinoõhtuid, talguid ja muid kohalikele elanikele suunatud ettevõtmisi avalikus ruumis. Juulis 2010 osalesin välitööde raames "koduse toidu laadana" välja kuulutatud üritusel, kus lasnamäelased ülejäänud tallinlasi võõrustavad, kuid mis sellisel kujul toimima ei hakanud: kodukohviku stiilis lette oli ükskuid ja osalejaid pigem vähe (välitöömärkmed 02.-03.07.2010). Selle taustal tähistab Lasnaidee ellukutsumine ja püsimajäämine huvitavat ja olulist nihet. Küsimus, kas ja kuidas mõjutavad Lasnaidee algatused majanaabrite läbikäimist, vääriks eraldi uurimist.

\section{Allikad}

Kask, Eve 2004. Fotoseeria Lasnamäe elanikest. Käsikiri [Eve Kase valduses].

\section{Kirjandus}

Alver, Marika \& Taavet, Ave 2017. Etnograafilise uurimismaterjali (re)presenteerimisvõimalused. Goršič, Ave \& Annom, Inge (toim). Ristteel. Pro Folkloristica XVIII. Tartu: EKM Teaduskirjastus, lk 104-116.

Annist, Aet \& Kaaristo, Maarja \& Cubero, Carlo \& Jõesalu, Kristi \& Kõresaar, Ene \& Järv, Ehti 2017. Antropoloogia metodoloogia. Annist, Aet \& Kaaristo, Maarja (koost \& toim). Sotsiaal-ja kultuuriantropoloogia. Õpik kõrgkoolidele. Tallinn: TLÜ Kirjastus, lk 60-96.

Benschop, Ruth 2020. A Thought Experiment on Artistic Research as High-Risk Ethnography. Borgdorff, Henk \& Peters, Peter \& Pinch, Trevor (toim). Dialogues Between Artistic Research and Science and Technology Studies. New York \& London: Routledge, lk 46-60 (doi: 10.4324/9780429438875-4). 
Biggs, Michael \& Karlsson, Henrik (toim) 2011. The Routledge Companion to Research in the Arts. London \& New York: Routledge.

Borgdorff, Henk 2012. The Conflict of the Faculties: Perspectives on Artistic Research and Academia. Leiden: Leiden University Press.

Borgdorff, Henk \& Peters, Peter \& Pinch, Trevor (toim) 2020. Dialogues Between Artistic Research and Science and Technology Studies. New York \& London: Routledge.

Brubaker, Rogers 2006. Ethnicity without Groups. Cambridge, Mass. \& London, England: Harvard University Press.

Brubaker, Rogers \& Feischmidt, Margit \& Fox, Jon \& Grancea, Liana 2006. Nationalist Politics and Everyday Ethnicity in a Transylvanian Town. Princeton: Princeton University Press.

Brubaker, Rogers \& Loveman, Mara \& Stamatov, Peter 2004. Ethnicity as Cognition. Theory and Society 33 (1), lk 31-64 (doi: 10.1023/B:RYSO.0000021405.18890.63).

Clifford, James 1988. The Predicament of Culture: Twentieth-Century Ethnography, Literature, and Art. Cambridge \& London: Harvard University Press.

Clifford, James \& Marcus, George E. (toim) 1986. Writing Culture: The Poetics and Politics of Ethnography. Berkeley \& Los Angeles \& London: University of California Press.

Coles, Alex 2000. Sites-specificity: The Ethnographic Turn. London: Black Dog Press.

Dombois, Florian 2006. Kunst als Forschung. Ein Verscuch, sich selbst eine Einleitung zu entwerfen. What's Next? (http://whtsnxt.net/044 - 18. juuni 2020).

Dombois, Florian 2017. <FLORIAN.DOMBOIS@ZHDK.CH>KIRJOITTI 17.6.2017 12.04:. Kaila, Jan \& Seppä, Anita \& Slager, Henk (toim). Futures of Artistic Research: At the Intersections of Utopia, Academia and Power. Writings from the Academy of Fine Arts 5. Helsinki: The Academy of Fine Arts, Uniarts, lk 73-81 (https://helda. helsinki.fi/bitstream/handle/10138/246117/Futures_of_artistic_research_kirja. pdf? sequence=1\&isAllowed=y -18 . juuni 2020).

Dombois, Florian \& Hiltbrunner, Michael 2019. Is this the end? Or is it a beginning? OAR: The Oxford Artistic and Practice Based Research Platform 3. (http://www.oarplatform. com/is-this-the-end-or-is-it-a-beginning/ - 18. juuni 2020).

Foster, Hal 1995. The Artist as Ethnographer? Marcus, George E. \& Myers, Fred R. (toim). The Traffic in Culture: Refiguring Art and Anthropology. Berkeley \& Los Angeles \& London: University of California Press, lk 302-309.

Grimshaw, Anna \& Owen, Elspeth \& Ravetz, Amanda 2010. Making Do: The Materials of Art and Anthropology. Schneider, Arnd \& Wright, Christopher (toim). Between Art and Anthropology: Contemporary Ethnographic Practice. Oxford \& New York: Berg, lk 147-162. 
Grimshaw, Anna \& Ravetz, Amanda 2015. The Ethnographic Turn - and After: A Critical Approach Towards the Realignment of Art and Anthropology. Social Anthropology/ Anthropologie Sociale 23 (4), lk 418-434 (doi:10.1111/1469-8676.12218).

Hatšaturjan, Aida 2012. Noored vene haritlased Eestiga seotud põlvkondliku identiteedi otsinguil. Aarelaid-Tart, Aili (koost). Nullindate kultuur II. Põlvkondlikud pihtimused. Tartu: Tartu Ülikooli Kirjastus, lk 182-212.

Hirschauer, Stefan 2006. Putting things into words. Ethnographic description and the silence of the social. Human Studies 29, lk 413-441 (doi: 10.1007/s10746-007-9041-1).

Ingold, Tim 2013. Making: Anthropology, Archaeology, Art and Architecture. London: Routledge.

Jackson, Jason Baird \& Jõeste, Kristi \& Matsin, Ave \& Rennu, Madis 2019. Asja uuritakse. Mõttevahetus materiaalse kultuuri uurimise üle Eestis ja Ameerika Ühedriikides. Asja uuritakse. Studia Vernacula 10, lk 102-120.

Jaschik, Scott 2018. 'Talking Art'. Inside Higher Education 27.09.2018 (https://www. insidehighered.com/print/news/2018/09/27/author-discusses-his-new-book-based-closeobservation-visual-arts-mfa-programs - 18. juuni 2020).

Juske, Ants 2009. Mis nägu on eestlane? Mis nägu olen mina? Eesti Päevaleht 11.02.2009 (https://epl.delfi.ee/kultuur/mis-nagu-on-eestlane-mis-nagu-olen-mina?id=51158599 18. juuni 2020).

Kaila, Jan \& Seppä, Anita \& Slager, Henk (toim) 2017. Futures of Artistic Research: At the Intersections of Utopia, Academia and Power. Writings from the Academy of Fine Arts 5. Helsinki: The Academy of Fine Arts, Uniarts.

Kask, Eve 2003. Käsmu inimesed ja majad 1999-2003. Tallinn: E. Kask.

Kask, Eve 2008. Eesti bussiputkade peaaegu täielik teejuht 2004-2007. Tallinn: Tänapäev.

Kask, Eve 2019. Käsmu inimesed ja majad [II]. 20 aastat hiljem: 2013-2019. Käsmu \& Tallinn: E. Kask.

Kelomees, Raivo 2014. Specialized competence of art audiences and the signature of technology artists: a look at the history of artsicence and criteria for evaluating it. Piirma, Piibe \& Valk, Veronika (toim). Rhizope. Art \& Science - Hybrid Art and Interdisciplinary Research. Tallinn: Eesti Kunstiakadeemia, lk 11-21.

Kelomees, Raivo 2018. Loomeuurimuspalavik. kunst.ee 4 (https://ajakirikunst. ee/?c=kunstee-numbrid\&l=et\&s=otsi\&t=loomeuurimuspalavik\&id=2060 - 22. mai 2020).

Kisin, Eugenia \& Myers, Fred R. 2019. The Anthropology of Art, After the End of Art: Contesting the Art-Culture System. Annual Review of Anthropology 48, lk 317-334 (doi: 10.1146/annurev-anthro-102218-011331). 
Kjørup, Søren 2011. Pleading for Plurality: Artistic and Other Kinds of Research. Biggs, Michael \& Karlsson, Henrik (toim). The Routledge Companion to Research in the Arts. London \& New York: Routledge, lk 44-63.

Kuutma, Kristin 2005. Pärimuskultuurist kultuurisümboliks. Saami etnograafia ja seto eepose saamislugu. Tartu: Eesti Kirjandusmuuseum.

Ladõnskaja, Viktoria 2013. Lasnamäe valge laev. [Tartu:] Petrone Print.

Ladõnskaja, Viktoria \& Pavlenko, Tatjana 2007. Maja, kust eestlased ära kolivad. Eesti Ekspress 22.11.2007 (https://ekspress.delfi.ee/kuum/maja-kust-eestlased-arakolivad?id=69151429 -18 . juuni 2020).

Lankots, Epp 2016. Loomeuurimus - kas kunst või teadus? Sirp 04.11.2016 (https:// www.sirp.ee/s1-artiklid/c6-kunst/loomeuurimus-kas-kunst-voi-teadus/ - 18. juuni 2020).

Lawless, Elaine 1992. "I Was Afraid Someone like You... an Outsider... Would Misunderstand": Negotiating Interpretive Differences between Ethnographers and Subjects. Journal of American Folklore 105 (417), lk 302-314 (doi: 10.2307/541758).

Lember, Uku 2015. Rahvus, kooselu ja vaikus. Eesti-vene pered Nõukogude Eestis. Sirp 18.09.2015 (http://www.sirp.ee/s1-artiklid/c9-sotsiaalia/rahvus-kooselu-ja-vaikus/ 18. juuni 2020).

Levitt, Peggy \& Glick Schiller, Nina 2004. Conceptualizing Simultaneity: A Transnational Social Field Perspective on Society. International Migration Review 38 (3), lk 1002-1039 (doi: 10.1111/j.1747-7379.2004.tb00227.x).

Lippard, Lucy R. 2010. Farther Afield. Schneider, Arnd \& Wright, Christopher (toim). Between Art and Anthropology: Contemporary Ethnographic Practice. Oxford \& New York: Berg, lk 23-34.

Loor, Egle \& Orn, Andra 2020. Olemata näituste olemus: Kuidas rääkida salapaigast seda reetmata. Noar.eu. Access art! (https://noar.eu/et/olemata-naituste-olemus-kuidasraakida-salapaigast-seda-reetmata/ - 18. juuni 2020).

Lorenz, Renate 2017. Unfinished Glossary of Artistic Research. Kaila, Jan \& Seppä, Anita \& Slager, Henk (toim). Futures of Artistic Research: At the Intersections of Utopia, Academia and Power. Writings from the Academy of Fine Arts 5. Helsinki: The Academy of Fine Arts, Uniarts, lk 31-46.

Marcus, George E. 2010. Affinities: Fieldwork in Anthropology Today and the Ethnographic in Artwork. Schneider, Arnd \& Wright, Christopher (toim). Between Art and Anthropology: Contemporary Ethnographic Practice. Oxford \& New York: Berg, lk 83-94.

Marcus, George E. \& Myers, Fred R. (toim) 1995. The Traffic in Culture: Refiguring Art and Anthropology. Berkeley \& Los Angeles \& London: University of California Press. 
Mullen, Patrick B. 2000. Collaborative Research Reconsidered. Journal of Folklore Research 37 (2/3) Special Double Issue Issues in Collaboration and Representation, lk 207-214.

Pesti, Madli 2018. Mis on loomeuurimus? Tantsu KuuKiri 74 (http://kuukiri.tantsuliit. ee/artikkel/mis-on-loomeuurimus/ - 18. juuni 2020).

Piirma, Piibe \& Valk, Veronika (toim) 2014. Rhizope. Art \& Science - Hybrid Art and Interdisciplinary Research. Tallinn: Eesti Kunstiakadeemia.

Pink, Sarah 2001. Doing Visual Ethnography. Images, Media and Representation in Research. London \& Thousand Oaks \& Delhi: SAGE Publications.

Pink, Sarah 2006. The Future of Visual Anthropology: Engaging the senses. London \& New York: Routledge.

Polanyi, Michael 1962. Tacit Knowing: Its Bearing on Some Problems of Philosophy. Review of Modern Physics 34 (4), lk 601-616 (doi: 10.1103/RevModPhys.34.601).

Rutten, Kris \& van Dienderen An \& Soetaert, Ronald 2013. Revisiting the ethnographic turn in contemporary art. Critical Arts 27 (5), lk 459-473 (doi: 10.1080/02560046.2013.855513).

Schneider, Arnd \& Wright, Christopher 2010. Between Art and Anthropology. Schneider, Arnd \& Wright, Christopher (toim). Between Art and Anthropology: Contemporary Ethnographic Practice. Oxford \& New York: Berg, lk 1-22.

Seljamaa, Elo-Hanna 2011. Tähenduslikud marginaalid Liina Siibi pilgu läbi. kunst.ee 1-2 (http://ajakirikunst.ee/?c=kunstee-numbrid\&l=et\&t=tahenduslikud-marginaalidliina-siibi-pilgu-labi\&id=364 - 18. juuni 2020).

Seljamaa, Elo-Hanna 2012. A Home for 121 Nationalities or Less: Nationalism, Ethnicity and Integration in Post-Soviet Estonia. $\mathrm{PhD}$ dissertation. Columbus, Ohio: The Ohio State University.

Seljamaa, Elo-Hanna 2014. Participating in public displays of nationalism, shamelessly: Eva Sepping and her trilogy on nationalism. Estonian Art 14/1, lk 32-34.

Seljamaa, Elo-Hanna 2016. Silencing and amplifying ethnicity in Estonia: An ethnographic account from Tallinn. Ethnologia Europaea 46 (2). Special issue: Silence in Cultural Practices, lk 27-43.

Seljamaa, Elo-Hanna 2019. Hargmaine paradiisi poliitika. Sirp 21.03.2019 (https://www. sirp.ee/s1-artiklid/c6-kunst/hargmaine-paradiisi-poliitika/ - 18. juuni 2020).

Seljamaa, Elo-Hanna \& Siim, Pihla Maria 2016. Where does silence take us, if we listen to it. Ethnologia Europaea 46 (2). Special issue: Silence in Cultural Practices, lk 5-13.

Siegenthaler, Fiona 2013. Towards an ethnographic turn in contemporary art scholarship. Critical Arts 27 (6), lk 737-752 (doi: doi.org/10.1080/02560046.2013.867594). 
Siukonen, Jyrki 2016. Vasar ja vaikus. Lühike sissejuhatus tööriistade filosoofiasse. Tallinn: Eesti Kunstiakadeemia Kirjastus.

Triisberg, Airi 2016. Feministlikud kunstistrateegiaid migratsioonidebatis. Kunst.ee 2 (https://ajakirikunst.ee/?c=kunstee-numbrid\&l=et\&t=feministlikud-kunstistrateegiadmigratsioonidebatis\&id=1543 - 18. juuni 2020).

Truvillion, Jesse G. 2000. Singing a New Song: Notes on Redemption. Journal of Folklore Research 37 (2/3). Special Double Issue. Issues in Collaboration and Representation, lk 215-226.

Tsinhnahjinnie, Hulleah J. 2020 [1998]. When Is a Photograph Worth a Thousand Words? (https://hulleah.com/9to5/1000words.htm - 18. juuni 2020).

Van Klaveren, Rosanne 2014. Wolf Within: Should artists conducting academic research wear sheep' clothing. Piirma, Piibe \& Valk, Veronika (toim). Rhizope. Art \& Science Hybrid Art and Interdisciplinary Research. Tallinn: Eesti Kunstiakadeemia, lk 99-103.

\title{
Summary
}

\section{Ethnographic fieldwork in the mirror of art}

\author{
Elo-Hanna Seljamaa \\ Senior Research Fellow \\ Department of Estonian and Comparative Folklore, University of Tartu, Estonia \\ elo-hanna.seljamaa@ut.ee
}

Keywords: artistic research, contemporary art, empirical cultural research, ethnicity, ethnography, fieldwork, Lasnamäe

The article aims to bring together debates surrounding the use of ethnographic methods in contemporary art, and attempts to theorize and define artistic research or "research in the arts". It stems from concern about differences and overlaps between the application of ethnographic methods in contemporary art and in folkloristics, ethnology and cultural anthropology, referred to here as empirical cultural research. Contemporary artists and researchers might rely on the same qualitative methods (e.g. interviewing and participant observations) in order to collect and generate data for their works, and they might even address the same or similar topics. Nevertheless, their approaches, working processes, results, and concerns differ in fascinating ways that tend to escape definition. A picture is worth a thousand words, but researchers seem to be shackled by language, especially when trying to capture the ambiguity that often characterizes the making and undoing of belonging and non-belonging. However, both researchers and artists employ ethnographic methods as their own working instruments, and their work is heavily dependent on the goodwill of others. Moreover, both art and ethnography have the ability to draw our attention to the obvious and the unseen, to show the familiar from a new and unexpected angle. 
The empirical starting points for the article are the author's ethnographic fieldwork on ethnic interactions in Lasnamäe, a part of Tallinn commonly associated with Soviet-era apartment complexes and Russian-speaking immigrants, and Kärberi 37, a series of 49 portraits by the Estonian artist Eve Kask of her neighbors in the same district. Both the author and the artist are Estonian-speaking natives of Tallinn. The article discusses how their work required them to go beyond, and even transgress, the tacit norms of interethnic coexistence that call for the silencing of ethnicity. Shared by the capital's residents, these unspoken rules contribute on a daily basis to the separateness of ethnic Estonians and Russian-speakers. While an ethnographer concerned with research ethics and anonymity might not dream of exhibiting photographs of her interlocutors, in the context of an artistic project portraits become a mirror reflecting viewers' implicit assumptions, Estonian society, and ethnographic practices. Providing an overview of diverse approaches to artistic research, the article supports the view that artistic research is not a new discipline, but intrinsic to art.

Elo-Hanna Seljamaa on Tartu Ülikooli eesti ja võrdleva rahvaluule osakonna vanemteadur, keda huvitab etnilisus ja laiemalt kuulumine ning erinevustega toimetulemine nii argielus kui pidulikumatel puhkudel. Koostöös Pihla Maria Siimu ja Anastasiya Astapovaga on tal käsil Eesti Teadusagentuuri rahastatav stardigrant "Folkloristlik vaade kuulumisele ja mitte-kuulumisele Eestis" (2018-2021).

Elo-Hanna Seljamaa is Senior Research Fellow at the Department of Estonian and Comparative Folklore at the University of Tartu. Her research interests cover ethnicity and, on a larger scale, belonging and managing differences both in everyday life and on more festive occasions. Together with Pihla Maria Siim and Anastasiya Astapova she is engaged in the start-up grant "Performative negotiations of belonging in contemporary Estonia" (2018-2021), financed by the Estonian Research Council.

elo-hanna.seljamaa@ut.ee 